\title{
Effect of Sodium Substitution on Lactic Acid Bacteria and Total Bacterial Population in Mango Pickle
}

\author{
Arghya Mani ${ }^{*}$, Prodyut Kumar Paul ${ }^{2}$ and Ivan Wilson ${ }^{3}$ \\ ${ }^{1}$ Department of Post-harvest Technology, BCKV, Mohanpur, India \\ ${ }^{2}$ Department of Pomology and Post-harvest Technology, UBKV, Coochbehar, India \\ ${ }^{3}$ Warner School of Food and Dairy, SHUATS, Allahabad, India \\ *Corresponding author
}

\begin{tabular}{|c|}
\hline Keywords \\
\hline $\begin{array}{l}\text { Lactic acid bacteria, } \\
\text { Salt substitution, } \\
\text { Bacterial population, } \\
\text { LAB. }\end{array}$ \\
\hline Article Info \\
\hline $\begin{array}{l}\text { Accepted: } \\
\text { 17 September } 2017 \\
\text { Available Online: } \\
\text { 10 November } 2017\end{array}$ \\
\hline
\end{tabular}

\section{A B S T R A C T}

An attempt has been made to prepare mango pickle using different salt compositions of $\mathrm{NaCl}, \mathrm{KCl}$ and $\mathrm{CaCl}_{2}$ and evaluate the pickle samples for total bacterial population and Lactic acid bacteria populations. The purpose of salt mixture was to reduce $\mathrm{Na}$ consumption. The results showed that the total bacterial population tends to increase with storage. Minimum bacterial population was observed at 0 day and maximum at $210^{\text {th }}$ day of storage. Among different treatments, $\mathrm{T}_{1}$ and $\mathrm{T}_{2}$ showed maximum bacterial population of 164 and 160 respectively, whereas minimum bacterial colonies was observed in $\mathrm{T}_{5}$ (147.67). It clearly indicates that $\mathrm{CaCl}_{2}$ has a negative influence on bacterial population. The Lactic Acid Bacteria population shows a reverse trend and tends to decline with storage time. At 0 day, $T_{1}$ shows highest population of LAB (162.67) followed by $T_{2}$ (139.67), $\mathrm{T}_{6}$ (137.67) and $\mathrm{T}_{4}$ (135.67); whereas $\mathrm{T}_{5}$ showed lowest $\mathrm{LAB}$ population (114.33). At $210^{\text {th }}$ day, $\mathrm{T}_{6}$ showed highest $\mathrm{LAB}$ population (50.67) followed by $\mathrm{T}_{1}(47)$. $\mathrm{T}_{5}$ supported lowest LAB population (25) followed by $\mathrm{T}_{3}(30.33), \mathrm{T}_{2}(32)$ and $\mathrm{T}_{4}(34)$. This clearly shows that $\mathrm{NaCl}$ and $\mathrm{KCl}$ have positive influence on $\mathrm{LAB}$ population. A conclusion can be drawn from this that the incorporation of $\mathrm{CaCl}_{2}$ in the salt mixture which is to be used for curing purpose directly helps to suppress the bacterial population even at $210^{\text {th }}$ day ( 7 month) of storage. But it also affects the growth of desirable Lactic Acid Bacteria (LAB) in the pickle. Hence, a salt mixture with $50 \% \mathrm{NaCl}, 25 \% \mathrm{KCl}$ and $25 \% \mathrm{CaCl}_{2}$ can be used for pickle preparation.

\section{Introduction}

Mango pickle is one of the oldest preserved food products which is made from unripe mango. The term pickle is derived from the Dutch word 'Pekel", meaning brine (Wikipedia, 2017). Pickles are made through the natural fermentation of fruits and vegetables, and besides having nutritional value, pickles also act as a food accompaniments and palatability enhancers
(Savitri and Bhalla, 2007). The process of pickling involves fermentation which is a primitive preservation method primarily used to enable the long-term storage of foods. Fermentation is a slow decomposition process of organic substances induced by microorganisms or enzymes that essentially convert carbohydrates to alcohols or organic acids (FAO, 1998). When the fermentation 
term is used in case of fruits and vegetables, it is known as pickling. Out of the various approaches to fermentation, lactic acid fermentation, using natural micro flora or lactic acid bacterial (LAB) cultures, is employed throughout the world. Lactic acid (LA) fermentation of vegetables and fruits is a common practice to maintain and improve the nutritional and sensory features of food commodities (Cagno et al., 2013; Karovicova and Kohajdova, 2003). Salt is an indispensable part of our food habit. Salts not only improve the taste, but it also has a big role in human nutrition. $\mathrm{NaCl}$ is one of the most commonly employed agents for food conservation, allowing considerable increase in storage time by reducing water activity. Salt (sodium chloride) is the oldest food seasoning, which provides one of the important basic human tastes (saltiness) and preserves foods to extend the shelf life. Salt mainly consists of two elements: sodium and chloride. In the pickling industry, salt has historically been used for directing the fermentation of cucumbers, radishes, and carrots (Thompson et al., 1979; Hudson and Buescher, 1985; Fleming et al., 1995; Mcfeeters et al., 1996). Common salt contains $\mathrm{Na}^{+}$(Cation) and $\mathrm{Cl}^{-}$(Anion). $\mathrm{Na}^{+}$(Cation) is mainly responsible for the saltiness in the food. Sodium is a vital element required in small amounts by the human body, as it helps to control homeostasis and nerve impulses (Starr and McMillan, 2006). Sodium chloride is an essential in food as it improves the preservative, technological and sensory quality of food (Brady, 2002). The extra intake of sodium present in salt might lead to conditions such as hypertension and high blood pressure. Approximately one quarter of the world's population suffers from this condition (WHO, 2011). High sodium intake is increasing the risk of heart attack and high blood pressure (Doyle, 2008). Results for sodium intake and its effects on human blood pressure were derived from scientific research, animal studiesand other human surveys (Doyle, 2008; Kesteloot and Joossens, 1988; Meneton et al., 2005). The mechanism of the effect of salt on blood pressure could be due to the rise in plasma sodium or to the increase in extracellular fluid volume. Higher dietary sodium intake is also related to bone disease (Doyle, 2008). Pickling is done in presence of high concentration of salt solution in which the fruit pieces are dipped to ensure fermentation. Pickles contain salt at about 15-20\% levels making it one of the high salt containing foods. The biggest drawback with pickles is the presence of high concentration of sodium ion $\left(\mathrm{Na}^{+}\right)$which may lead to adverse effects on human health and on food business. Many food products have been launched in its low salt version. The only form of salt that does not contain sodium is the low-sodium alternatives are the replacement with Potassium, Magnesium and Calcium ion instead of sodium. Eating excess salt raises the amount of sodium in our bloodstream and disturbs the delicate balance, reducing the ability of our kidneys to remove the water. The partial substitution of $\mathrm{NaCl}$ by $\mathrm{KCl}$ or $\mathrm{CaCl}_{2}$ seems to provide an alternative for reducing sodium content. Increased potassium intake is reported to protect stroke, high blood pressure, heart rhythm problems, kidney failure, and even osteoporosis (Hall, 2003). The additional use of $\mathrm{KCl}$ and $\mathrm{CaCl}_{2}$ to partially replace $\mathrm{NaCl}$ could be helpful in reducing sodium content (Gillette, 1985). However, the use of $\mathrm{KCl}$ is mainly limited by its bitter and astringent taste (Reddy and Marth, 1991). Some people have reported a metallic after taste and therefore choose not to use $\mathrm{KCl}$ in food. But a mixed concentration of $\mathrm{Na}, \mathrm{K}$ and $\mathrm{Ca}$ can help to reduce the total salt intake in our body. Therefore, the present work has been undertaken to investigate the possibility of replacing sodium chloride by potassium and Calcium salts and develop low sodium mango pickle, to study the effect of 
partial $\mathrm{NaCl}$ substitution on processing parameters of pickles, to study the effect of $\mathrm{NaCl}$ substitution of sensory properties of pickle and to optimize salt mixture components for low sodium mango pickles without affecting its physiochemical, biochemical, microbiological and sensory qualities.

\section{Materials and Methods}

\section{Site of experiment}

The present study was conducted in Post Graduate Laboratory, Department of Pomology and Post-Harvest Technology, Faculty of Horticulture and Central Instrumentation Centre Lab of Uttar Banga Krishi Viswavidyalaya, Pundibari, Coochbehar, West Bengal.

\section{Source of pickling materials}

The fruits were fresh, unripe and were free from pests, diseases and blemishes. Fazli variety was procured from local market since it is known to have high acid content. The chemical purchased were of Laboratory grade.

\section{Design for deciding the salt mixture for pickle preparation in the experiment}

The following design was used for deciding the salt mixture for pickle preparation in the experiment.

Design: Randomized Block Design (RBD) Software used: SPSS

\section{Procedure for mango pickle preparation}

Pickles were prepared by using the standardized procedure. The prepared pickles were stored in glass jars which were cleaned properly and were sterilized in boiling water at room temperature. During the entire storage period it was ensured that the pickle was stored in aerated, dry and hygienic conditions.

Lactic acid bacteria and total plate count upto $210^{\text {th }}$ day of pickle storage

The entire microbiological aspects of the experiment were performed in Post Graduate Lab, Department of Plant Pathology, UBKV. Microbiological analysis for the pickle was carried out by the method of Ranganna (1977). All the enumerations of Bacteria and Lactobacillus were carried out following serial dilution technique using specific media. Plates were incubated at $34 \pm 1{ }^{\circ} \mathrm{C}$ for 48 hours and colony forming units (CFU/g) were recorded. Observations for microbial count were made at prescribed intervals. The principle behind this is that the population of total bacterial population tends to decline with the decimal reduction in the concentration of the sample analyzed. Usually in a culture the microbial population was expected to be higher in $10^{-1}$ which tends to decline with $10^{-2}, 10^{-3}, 10^{-4}, 10^{-5}$ and $10^{-6}$ sample concentration. Higher the sample concentration higher would be the expected microbial concentration. As the colonies tends to coalesce or merge at higher concentration hence the readings for Total Plate Count and Total Bacterial Population Count has been studied at $10^{-5}$ concentration.

\section{Results and Discussion}

Table 2 shows the effect of different salt proportion on Lactic Acid Bacteria population in the mango pickle sample which has been studied upto $210^{\text {th }}$ day of preparation. Varying proportion of $\mathrm{NaCl}, \mathrm{KCl}$ and $\mathrm{CaCl}_{2}$ has been used for the curing purpose. At the 0 day of storage, $\mathrm{T}_{1}$ shows highest population of Lactic acid bacteria (162.67) followed by $T_{2}$ (139.67), $\mathrm{T}_{6}(137.67)$ and $\mathrm{T}_{4}(135.67)$ whereas $\mathrm{T}_{5}$ showed lowest LAB population (114.33). This can be attributed due to the fact that $\mathrm{KCl}$ and $\mathrm{CaCl}_{2}$ have a negative response on any 
sort of microbial growth. At $30^{\text {th }}$ day of storage, $\mathrm{T}_{1}$ have highest $\mathrm{LAB}$ population (154) followed by $\mathrm{T}_{2}$ (137.67), $\mathrm{T}_{6}$ (135.33) and $\mathrm{T}_{4}$ (133.33). $\mathrm{T}_{5}$ have lowest LAB population (111) followed by $\mathrm{T}_{3}$ (114.67). Similar trend in the LAB population dynamics has been observed at $60^{\text {th }}, 90^{\text {th }}$, $120^{\text {th }}, 150^{\text {th }}$ and $180^{\text {th }}$ day. At $210^{\text {th }}$ day, T6 showed highest LAB population (50.67) followed by $\mathrm{T}_{1}$ (47). $\mathrm{T}_{5}$ supported lowest LAB population (25) followed by $\mathrm{T}_{3}$ (30.33), $\mathrm{T}_{2}$ (32) and $\mathrm{T}_{4}$ (34). At $210^{\text {th }}$ day of storage, LAB population using $\mathrm{T}_{1}$ and $\mathrm{T}_{6}$ salt proportion is at par. This clearly shows that $\mathrm{NaCl}$ and $\mathrm{KCl}$ have positive influence on $\mathrm{LAB}$ population whereas addition of $\mathrm{CaCl}_{2}$ in salt mixture resulted in reduction in $\mathrm{LAB}$ population. This can be due to the unique ability of $\mathrm{CaCl}_{2}$ to reduce the water activity of salt cured mango pieces.

Table 3 shows the effect of different salt proportions on the total bacterial population in mango pickle sample at ambient storage upto $210^{\text {th }}$ days. The total plate count showed significant variation of total bacterial population among different treatments. At 0 day, highest bacterial population was observed in $T_{1}$ (7.67) followed by $T_{2}(7), T_{4}$ (6) and $\mathrm{T}_{6}$ (5.33). Lowest bacterial population was observed in $\mathrm{T}_{5}$ (4.33) followed by $\mathrm{T}_{3}$ (5). $\mathrm{T}_{1}$ was at par with $\mathrm{T}_{2}$ which clearly indicates that the presence of higher amount of $\mathrm{NaCl}$ and no $\mathrm{CaCl}_{2}$ provides suitable environment for bacteria to survive. Similar trend was observed at $30^{\text {th }}, 60^{\text {th }}, 90^{\text {th }}, 120^{\text {th }}, 150^{\text {th }}$ and $180^{\text {th }}$ day of treatment. At $210^{\text {th }}$ day of treatment, the pickle prepared using salt composition $\mathrm{T}_{1}$ showed maximum bacterial colonies (164). High bacterial population was also observed in $\mathrm{T}_{2}$ (160). Comparatively lower bacterial population was observed in $\mathrm{T}_{5}$ (147.67) followed by $\mathrm{T}_{6}$ (150). The reason behind lowest bacterial population in $\mathrm{T}_{5}$ and lower bacterial population at $\mathrm{T}_{6}$ can be attributed to the salt composition that was used during the curing procedure. $\mathrm{T}_{5}$ salt mixture contain $50 \% \mathrm{CaCl}_{2}$ because of which the pickle prepared was having lowest bacterial count. $\mathrm{CaCl}_{2}$ is known to be a good curing agent that can substantially reduce the available water in tissue of pickle pieces thus reducing the water activity $\left(\mathrm{a}_{\mathrm{w}}\right)$ and resulting in lower total bacterial population.

Fig.1 Lactic Acid Bacteria population (log CFU) under ambient storage conditions

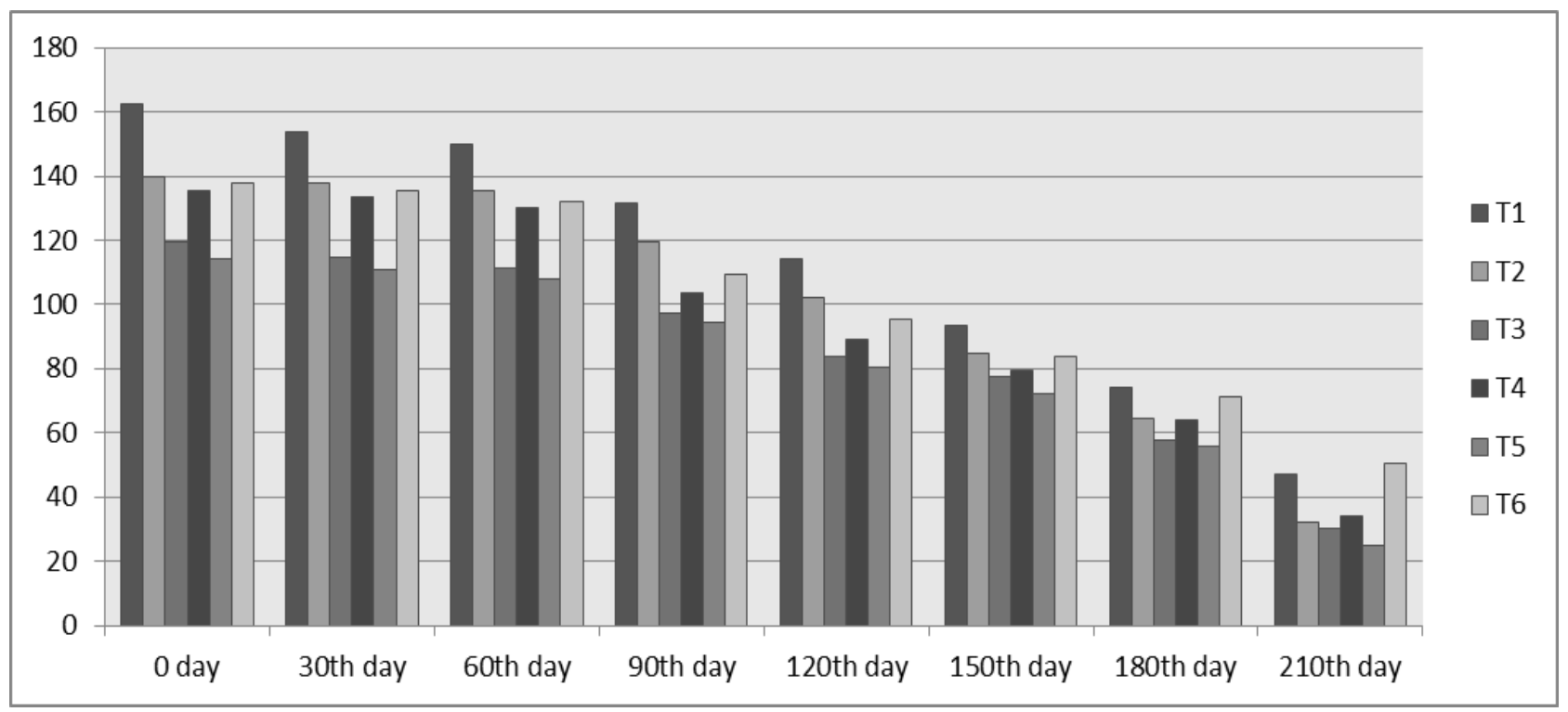


Fig.2 Total Bacterial population (log CFU) under ambient storage conditions

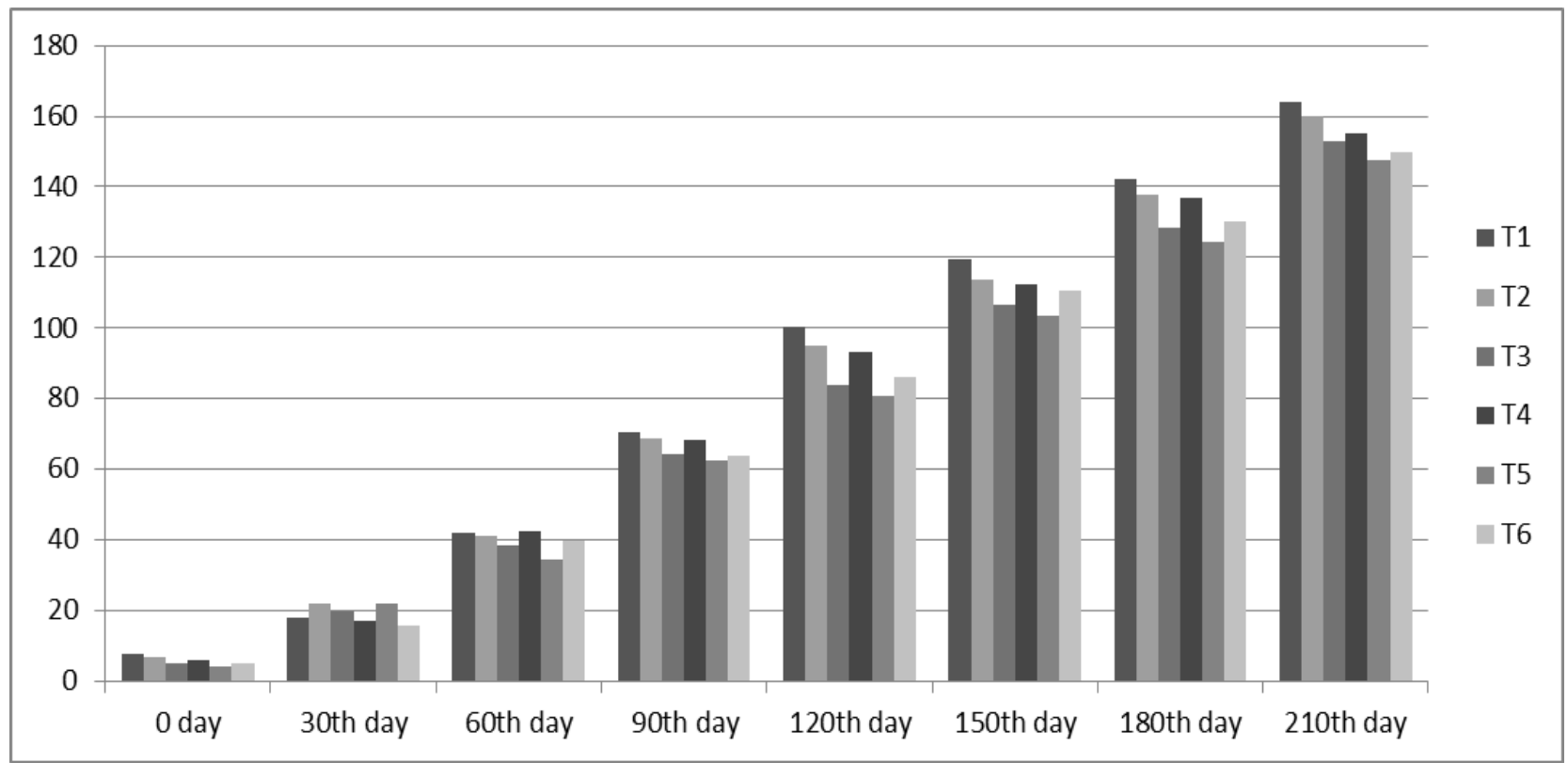

Table.1 Treatment details showing different salt proportion used for curing purpose

\begin{tabular}{llll}
\hline Treatment & $\mathbf{N a C l}(\boldsymbol{\%})$ & $\mathbf{K C l}(\boldsymbol{\%})$ & $\mathbf{C a C l}_{\mathbf{2}}(\boldsymbol{\%})$ \\
\hline $\mathrm{T} 1$ & 100 & 0 & 0 \\
\hline $\mathrm{T} 2$ & 50 & 50 & 0 \\
\hline $\mathrm{T} 3$ & 50 & 0 & 50 \\
\hline $\mathrm{T} 4$ & 0 & 100 & 0 \\
\hline $\mathrm{T} 5$ & 0 & 50 & 50 \\
\hline $\mathrm{T} 6$ & 50 & 25 & 25 \\
\hline
\end{tabular}

Table.2 Lactic Acid Bacteria population (log CFU) under ambient storage conditions

\begin{tabular}{|c|c|c|c|c|c|c|c|c|}
\hline 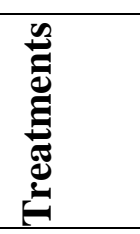 & $\frac{\vec{E}}{8}$ & 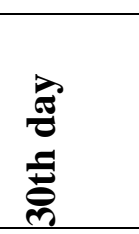 & 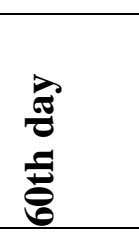 & 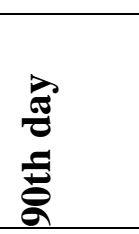 & 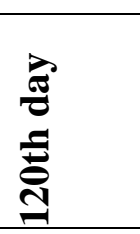 & 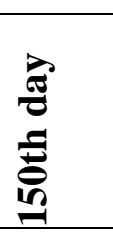 & 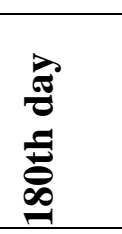 & 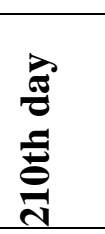 \\
\hline$T_{1}$ & 162.67 & 154 & 150 & 131.67 & 114 & 93.67 & 74.33 & 47 \\
\hline $\mathrm{T}_{2}$ & 139.67 & 137.67 & 135.33 & 119.67 & 102 & 85 & 64.33 & 32 \\
\hline $\mathrm{T}_{3}$ & 119.33 & 114.67 & 111.33 & 97.33 & 84 & 77.33 & 58 & 30.33 \\
\hline $\mathrm{T}_{4}$ & 135.67 & 133.33 & 130.33 & 103.67 & 89.33 & 79.33 & 64 & 34 \\
\hline $\mathrm{T}_{5}$ & 114.33 & 111 & 108 & 94.67 & 80.67 & 72.33 & 56 & 25 \\
\hline $\mathrm{T}_{6}$ & 137.67 & 135.33 & 132 & 109.33 & 95.33 & 84 & 71.33 & 50.67 \\
\hline C.D. & 17.776 & 15.795 & 13.335 & 12.231 & 11.526 & 7.229 & 5.201 & 3.314 \\
\hline SE(m) & 5.569 & 4.949 & 4.178 & 3.832 & 3.611 & 2.265 & 1.63 & 1.038 \\
\hline C.V. & 7.151 & 6.543 & 5.661 & 6.068 & 6.638 & 4.787 & 4.365 & 4.926 \\
\hline
\end{tabular}


Table.3 Total Bacterial population (log CFU) under ambient storage conditions

\begin{tabular}{|c|c|c|c|c|c|c|c|c|}
\hline 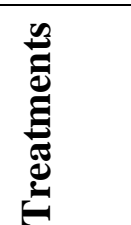 & t) & 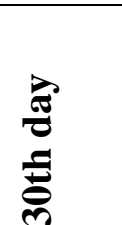 & 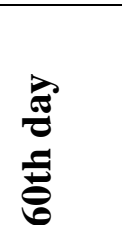 & 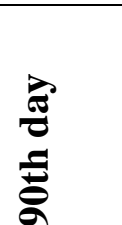 & 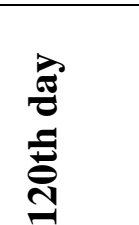 & 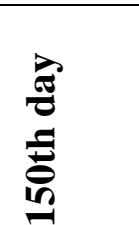 & 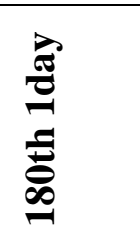 & 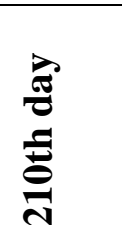 \\
\hline $\mathrm{T} 1$ & 7.67 & 18 & 42 & 70.67 & 100.33 & 119.33 & 142.33 & 164 \\
\hline $\mathrm{T} 2$ & 7 & 22 & 41 & 68.67 & 95 & 113.67 & 137.67 & 160 \\
\hline T3 & 5 & 20 & 38.33 & 64.33 & 84 & 106.67 & 128.33 & 153 \\
\hline $\mathrm{T} 4$ & 6 & 17 & 42.67 & 68.33 & 93.33 & 112.33 & 137 & 155.33 \\
\hline T5 & 4.33 & 22 & 34.67 & 62.67 & 80.67 & 103.67 & 124.33 & 147.67 \\
\hline T6 & 5.33 & 16 & 39.67 & 64 & 86.33 & 110.67 & 130 & 150 \\
\hline C.D. & 1.637 & 1.99 & 1.332 & 1.046 & 2.621 & 2.808 & 1.893 & 1.748 \\
\hline $\mathrm{SE}(\mathrm{m})$ & 0.513 & 0.624 & 0.417 & 0.328 & 0.821 & 0.88 & 0.593 & 0.548 \\
\hline C.V. & 15.083 & 5.635 & 1.819 & 0.854 & 1.581 & 1.372 & 0.771 & 0.612 \\
\hline
\end{tabular}

\section{Summary}

The mango pickle which was prepared after curing with different salt mixture was evaluated for total bacterial population and lactic acid bacteria (LAB) population. The results showed that the total bacterial population tends to increase with storage. Hence minimum bacterial population was observed at 0 day and maximum at $210^{\text {th }}$ day of storage. Among different treatments, $\mathrm{T}_{1}$ and $\mathrm{T}_{2}$ showed maximum bacterial population of 164 and 160 respectively, whereas minimum bacterial colonies was observed in $\mathrm{T}_{5}$ (147.67). It clearly indicates that $\mathrm{CaCl}_{2}$ has a negative influence on bacterial population.

The Lactic Acid Bacteria population shows a reverse trend and tends to decline with time. At 0 day of storage, $T_{1}$ shows highest population of Lactic acid bacteria (162.67) followed by $\mathrm{T}_{2}$ (139.67), $\mathrm{T}_{6}(137.67)$ and $\mathrm{T}_{4}$ (135.67) whereas $T_{5}$ showed lowest LAB population (114.33).At $210^{\text {th }}$ day, $\mathrm{T}_{6}$ showed highest LAB population (50.67) followed by $\mathrm{T}_{1}$ (47). $\mathrm{T}_{5}$ supported lowest LAB population (25) followed by $T_{3}$ (30.33), $T_{2}$ (32) and $T_{4}$ (34).This clearly shows that $\mathrm{NaCl}$ and $\mathrm{KCl}$ have positive influence on $\mathrm{LAB}$ population.
A conclusion can be drawn from this that the incorporation of $\mathrm{CaCl}_{2}$ in the salt mixture which is to be used for curing purpose directly helps to suppress the bacterial population even at $210^{\text {th }}$ day (7 month) of storage. But it also affects the growth of desirable Lactic Acid Bacteria (LAB) in the pickle. Hence, a salt mixture with $50 \% \mathrm{NaCl}$, $25 \% \mathrm{KCl}$ and $25 \% \mathrm{CaCl}_{2}$ can be used for pickle preparation. This salt mixture would not only help to minimize Sodium (Na) consumption but can also ensure a balanced microbial population throughout its ambient storage period to satisfactory level.

\section{References}

Brady M., (2002) Sodium survey of the usage and functionality of salt as an ingredient in UK manufactured food products. British Food Journal, 104: 84-125.

Di Cagno, R., R. Coda, M. De Angelis, and M. Gobbetti, (2013). Exploitation of vegetables and fruits through lactic acid fermentation. Food Microbiology, vol. 33, no. 1, pp. 1-10, 2013.

Doyle, M. E. (2008). Sodium reduction and its effects on food safety. Retrieved from University of Wisconsin-Madison, Food 
Research Institute website: http://fri.wisc.edu/docs/pdf/FRI_Brief_ Sodium_Reduction_11_08.pdf.

FAO, Fermented Fruits and Vegetables-A Global Perspective, vol.134, FAO Agricultural Services Bulletin, Rome, Italy, 1998.

Fleming H.P., Mcdonald L.C., Mcfeeters R.F., Thompson R.L., and Humphries E.G. (1995), Fermentation of cucumbers without sodium chloride, Journal of food science, Volume 60, No. 2, 1995, 312-319.

Gillette, M., (1985), Flavor effects of sodium chloride, Journal of Food Technology; $39,47-52$.

Hall, J.E. (2003), The kidney, hypertension, and obesity. Hypertension; 41, 625-633.

Harshvardhan Reddy and V. Chikkasubbanna (2010), The Asian Journal of Horticulture, (December, 2009 to May, 2010) Vol. 4 No. 2: 271-274.

Hudson, J.M. and Buescher, R.W. 1985. Pectic substances and firmness of cucumber pickles as influenced by $\mathrm{CaCl}_{2}, \mathrm{NaCl}$ and brine storage. Journal of Food Biochemistry, 9: 211-215.

Karovicova, J., and Z. Kohajdova, "Lactic acid fermented vegetable juices," Horticultural Science, vol. 30, pp. 152 158, 2003.

Kesteloot, H. andJoossens, J. V. (1988). Relationship of dietary sodium, potassium, calcium, and magnesium with blood pressure, hypertension:
Dietary electrolytes and blood pressure, Vol 12, No 6, December 1988, 594-599.

Mcfeeters, R.F., and H.P. Fleming (1996), Balancing macro mineral composition of fresh-pack cucumber pickles to improve nutritional quality and maintain flavor, Journal of Food Qualiy (1997) page- 81-89.

Meneton, P., Jeunemaitre, X., De Wardener, H. E. and MacGregor, G.A. (2005). Links between dietary salt intake, renal salt handling, blood pressure, and cardiovascular diseases. Physiological Reviews, 85, 679-715.

Ranganna, S., 1977, Manual of Analysis of Fruits and Vegetable products. Tata McGraw-Hill.

Savitri and Bhalla, T.C. 2007. Traditional foods and beverages of Himachal Pradesh. Indian Journal of Traditional Knowledge, 6(1): 17-24.

Starr and McMillan (2006), A book on 'Human Biology', Vol-7.

Thompson, R.L., Fleming, H.P., and Monroe, R.J. 1979. Effects of storage conditions on firmness of brined cucumbers. Journal of Food Science, 44: 843-846.

Wikipedia: online resource at http://en.wikipedia.org/wiki/Pickled_cu cumber, accessed on 23/2/2017

World Health Organization, (2011), Collaboration to optimize dietary intakes of salt and iodine. Internet: http://www.who.int/bulletin/volumes^9 0/11-092080/en/

\section{How to cite this article:}

Arghya Mani, Prodyut Kumar Paul and Ivan Wilson. 2017. Effect of Sodium Substitution on Lactic Acid Bacteria and Total Bacterial Population in Mango Pickle. Int.J.Curr.Microbiol.App.Sci. 6(11): 2199-2205. doi: https://doi.org/10.20546/ijcmas.2017.611.260 